\title{
Effect of Different Levels of Maize Cob Rind Biochar on Growth and Yield of Finger Millet
}

\author{
K. L. Jyothishree ${ }^{1 *}$, G. N. Thippeshappa ${ }^{1}$, Sharanappa Jangandi ${ }^{2}$, \\ B. C. Dhananjaya ${ }^{1}$ and O. Kumar ${ }^{3}$ \\ ${ }^{I}$ Department of Soil Science and Agricultural Chemistry, UAHS, College of Agriculture, \\ Shivamogga, India \\ ${ }^{2}$ Department of Agricultural Engineering, ZAHRS, Babbur Farm, Hiriyur, India \\ ${ }^{3}$ Agronomy, AHRS, Kathalagere, Davanagere District, India \\ *Corresponding author
}

\section{A B S T R A C T}

\section{Keywords}

Cob rind biochar,

Growth, Yield,

Finger millet

Article Info

Accepted:

04 October 2020

Available Online:

10 November 2020
A field experiment was conducted at Agricultural and Horticultural Research Station, Bavikere, University of Agricultural and Horticultural Sciences, Shivamogga during kharif 2019 to study the influence of cob rind biochar on growth, yield and nutrient uptake by finger millet. The experiment was conducted with 10 treatments consisting two levels of biochar at 2 and $4 \mathrm{t} \mathrm{ha}^{-1}$ and three levels of FYM at 5, 7.5 and $10 \mathrm{t} \mathrm{ha}^{-1}$ which were applied in combination with FYM or alone along with recommended dose of fertilizer. Treatments were imposed in randomized complete block design and were replicated thrice. The results revealed that application of higher dose of cob rind biochar@ $4 \mathrm{t} \mathrm{ha}^{-1}$ in combination with 100 per cent recommended dose of FYM and fertilizers recorded significantly higher growth and yield attributes such as plant height $(115.20 \mathrm{~cm})$, number of tillers hill ${ }^{-1}(3.35)$, dry matter production (55.20), number of ear heads hill ${ }^{-1}$ (4.56), number of fingers ear $\operatorname{head}^{-1}$ (7.73), test weight (3.68), grain yield (40.88 q ha-1) and straw yield (62.82 q ha-1) of finger millet compared to lower doses of biochar with or without FYM and control.

\section{Introduction}

Biochar is a carbon-rich organic solid material derived from biomass pyrolysis. It is found to play a crucial role in improvement of soil physical, chemical and biological properties. The importance of biochar for soil improvement is mainly due to its high surface area and more number of micro pores which helps in retention of nutrients and it also provide habitat and amicable environment for beneficial microorganisms of soil. It promotes storage of organic carbon (OC) in soil as it is rich source of carbon and it has ability to endure in soil for long period with very little biological decay (Lehmann et al., 2006). Its incorporation in the soil had been suggested to increase water holding capacity (Hesu et al., 2014), soil fertility (Liang et al., 2006) and enhance agricultural productivity (Ali $e t$ al., 2018). Biochar has been reported to improve nutrient availability to plants (Glaser 
et al., 2002). Biochar act as both amendment and nutrient source due to its ability to modify the soil $\mathrm{pH}$ by its alkaline nature and it is rich in nutrients such as $\mathrm{K}, \mathrm{Ca}, \mathrm{Mg}$ etc, respectively. There is ample evidence from studies that biochar plays a significant role in soil fertility and crop productivity. Biochar was described as one of the most important constituents of soil in fertile Chernozems (Schmitdt et al., 1999). Thus biochar improves the availability of nutrients which increases the soil fertility there by increasing the crop growth and yield. Finger millet is the principal dry land crop due to its resilience and ability to withstand aberrant weather conditions and generally grown in soils having poor water holding capacity and poor in fertility. In this backdrop the present investigation was carried out with the objective to know the effect of different levels of biochar on the growth and yield of finger millet.

\section{Materials and Methods}

A field experiment was conducted at AHRS, Bavikere, UAHS, Shivamogga during kharif 2019 to know the effect of cob rind biochar on growth and yield of finger millet.

The experiment comprised of 10 treatments with two different levels of cob rind biochar at 2 and $4 \mathrm{t} \mathrm{ha}^{-1}$ and at different level of reduced Rec. FYM at $10,7.5$ and $5 \mathrm{t} \mathrm{ha}^{-1}$ which are applied in combinations or applied alone. The recommended dose of fertilizer (RDF) is common for all the treatments except for absolute control $\left(\mathrm{T}_{1}\right)$. These 10 treatments were imposed in randomized complete block design (RCBD) with three replications. Cob rind biochar has recorded the $\mathrm{pH}$ of 8.07 , which found to be alkaline in nature. It has high total organic carbon of $72.84 \mathrm{~g} \mathrm{~kg}^{-1}$. Among the primary nutrients the biochar rich in K (1.09\%) followed by $\mathrm{N}$ $(0.53 \%)$ and $\mathrm{P}(0.09 \%)$.
Initial characterization of soil experimental site (Table 1) indicated that soil had a bulk density of $1.37 \mathrm{Mg} \mathrm{m}^{-3}$, maximum water holding capacity of 33.65 per cent and $\mathrm{pH}$ of 5.46 , electrical conductivity of $0.12 \mathrm{dS} \mathrm{m}^{-1}$, further the soil recorded medium available nitrogen status of $286 \mathrm{~kg} \mathrm{ha}^{-1}$, medium available phosphorous status (47.80 $\mathrm{kg} \mathrm{ha}^{-1}$ ) and medium available potassium status $\left(220.15 \mathrm{~kg} \mathrm{ha}^{-1}\right)$. The exchangeable $\mathrm{Ca}$ and $\mathrm{Mg}$ were 4.38 and $2.38 \mathrm{cmol}\left(\mathrm{p}^{+}\right) \mathrm{kg}^{-1}$, available sulphur was $16.51 \mathrm{mg} \mathrm{kg}^{-1}$ and the DTPA extractable micronutrients such as $\mathrm{Fe}$, $\mathrm{Zn}, \mathrm{Cu}$ and $\mathrm{Mn}$ recorded at 18.33, 1.49, 1.05 and $9.45 \mathrm{mg} \mathrm{kg}^{-1}$, respectively.

The soil texture was found to be sandy loam with sand content of 65.40 per cent, silt content of 14.35 per cent and clay content of 20.51 per cent. Finger millet (GPU-28) was choosen as test crop. Recommended dose of fertilizer for finger millet is 50:40:25 N, $\mathrm{P}_{2} \mathrm{O}_{5}$, $\mathrm{K}_{2} \mathrm{O} \mathrm{Kg} \mathrm{ha}{ }^{-1}$ and recommended dose FYM is $10 \mathrm{t} \mathrm{ha}^{-1}$. The growth attributes such as plant height, number of tiller hill ${ }^{-1}$ at different growth stages (30 DAT, 60 DAT and at harvest) and dry matter accumulation at harvest stage of finger millet was recorded. The yield attributes and yield such as number of ear heads hill ${ }^{-1}$, number of fingers ear head ${ }^{1}$, test weight, grain and straw yield at harvest stage of finger millet was recorded.

\section{Results and Discussion}

The data in Table 2 showed the effect of combined application of cob rind biochar and FYM on growth parameters such as plant height, number of tillers hill ${ }^{-1}$, dry matter production. The data indicated that there was a significant increase in the plant height $(\mathrm{cm})$, number of tillers hill $^{-1}$ at different growth stages and dry matter production at harvest stage of finger millet. Further, at a given level of cob rind biochar with the reduced recommended dose of FYM there was a 
decrease in plant height $(\mathrm{cm})$, number of tillers hill ${ }^{-1}$ and dry matter production.

\section{Plant height}

The plant height recorded at different growth stages of finger millet (Table 2) significantly varied among different treatments. Among the treatments, treatment $\mathrm{T}_{8}$ supplied with cob rind biochar@ $@ 4$ ha $^{-1}+100$ per cent Rec. FYM recorded significantly higher plant height (44.62, 99.9 and $115.20 \mathrm{~cm}$ at 30,60 DAT and at harvest respectively) of finger millet followed by treatment $\mathrm{T}_{9}$ (cob rind biochar@ $4 \mathrm{t} \mathrm{ha}^{-1}+75 \%$ Rec. FYM) which recorded 43.61, 97.27 and $113.23 \mathrm{~cm}$ respectively and treatment $\left(\mathrm{T}_{5}\right)$ received cob rind biochar@2 t ha ${ }^{-1}+100$ per cent Rec. FYM recorded 42.68, 96.40 and $111.36 \mathrm{~cm}$ respectively and found on par with each other when compared to other treatments. Whereas, the treatment $\mathrm{T}_{2}(\mathrm{RDF}+\mathrm{Rec} . \mathrm{FYM})$ recorded significantly lower plant height of 42.80, 94.86 and $107.39 \mathrm{~cm}$ respectively and absolute control treatment $\left(\mathrm{T}_{1}\right)$ where no cob rind biochar and FYM was applied recorded lowest plant height of 29.4056 .04 and 61.52 $\mathrm{cm}$ respectively.

\section{Number of tillers hill-1}

Data (Table 2) showed that, application of cob rind biochar@ $4 \mathrm{t} \mathrm{ha}^{-1}+100$ per cent Rec. FYM $\left(\mathrm{T}_{8}\right)$ recorded the highest number of tillers hill ${ }^{-1}(1.59,3.34$ and 3.35 at 30, 60 DAT and at harvest respectively) in finger millet followed by $\mathrm{T}_{9}(1.55,3.14$ and 3.22$)$ having the cob rind biochar@ $4 \mathrm{t} \mathrm{ha}^{-1}+75$ per cent Rec. FYM and treatment $\mathrm{T}_{5}$ (cob rind biochar @ 2 t ha ${ }^{-1}+100 \%$ Rec. FYM) recorded 1.52, 3.08 and 3.12 respectively and found on par with each other when compared to other treatments. Whereas, the treatment $T_{2}$ supplied with RDF + Rec. FYM (POP) which recorded lower number of tillers of 1.32, 3.04 and 3.06 respectively and the absolute control treatment $\left(\mathrm{T}_{1}\right)$ where no cob rind biochar and FYM was applied, which recorded lowest value of $0.13,1.28$ and 1.33 respectively.

\section{Total dry matter accumulation}

The data (Table 2) unveiled that the combined application of cob rind biochar and FYM significantly influenced the dry matter production of finger millet over control and alone application of cob rind biochar. Application of cob rind biochar @ $4 \mathrm{t} \mathrm{ha}^{-1}+$ 100 per cent Rec. FYM $\left(\mathrm{T}_{8}\right)$ recorded significantly higher dry matter yield $(55.20 \mathrm{~g}$ plant $^{-1}$ ) at the harvest stage of crop followed by treatment $\mathrm{T}_{9}$ (cob rind biochar @ $4 \mathrm{t} \mathrm{ha}^{-1}+$ $75 \%$ Rec. FYM) which recorded $53.30 \mathrm{~g}$ plant $^{-1}$ and the treatment $\mathrm{T}_{5}$ (cob rind biochar @ $2 \mathrm{t} \mathrm{ha}^{-1}+100 \%$ Rec. FYM) which recorded $51.51 \mathrm{~g} \mathrm{plant}^{-1}$ and found on par with each other when compared to other treatments. Whereas treatment which supplied with RDF + Rec. FYM as per POP $\left(\mathrm{T}_{2}\right)$ which recorded lower dry matter production of 46.89 g plant ${ }^{-1}$ but, significantly lowest dry matter production was recorded in absolute control $\left(\mathrm{T}_{1}\right)$ which recorded $38.12 \mathrm{~g}_{\text {plant }}{ }^{-1}$.

There were several factors which led to improved crop growth attributes with the addition of biochar to acid soil. In fact, biochar has a role in improving physical properties especially decrease in bulk density and increasing the water holding capacity of soil and chemical properties of soil.

The alkali nature of biochar increased the $\mathrm{pH}$ of acid soils and also at same time decreased the soluble $\mathrm{Al}$ and $\mathrm{Fe}$ species in Soil, It has a effect on a controlled and slow release of plant nutrients and there by increased nutrient availability and their supply for plant uptake. As a rich source of carbon which enhanced higher microbial activity in soil. These factors might have helped to boost the growth parameters finger millet over control. The 
results are corroborated with other research studies (Liang et al., 2006; Gundale and De Luca (2006); Chan et al., (2008); Blackwell et al., (2010); Dong et al., (2015) and Kalyani et al., (2016)).

\section{Yield attributes and yield}

The data recorded on yield attributes and yield of finger millet as influenced by the application of different levels of cob rind biochar in combination with or without FYM are presented in Table 3.

Among the different levels of cob rind biochar (i.e., 2 and $4 \mathrm{t} \mathrm{ha}^{-1}$ ), higher dose of cob rind biochar $\left(4 \mathrm{t} \mathrm{ha}^{-1}\right)$ recorded significantly higher number of ear heads hill ${ }^{-1}$, number of fingers ear head ${ }^{-1}$, test weight, grain yield and straw yield when compared to the lower dose of cob rind biochar $\left(2 \mathrm{t} \mathrm{ha}^{-1}\right)$ and at a given level of cob rind biochar with the reduced recommended dose of FYM there is a decrease in number of ear heads hill ${ }^{-1}$, number of fingers ear head ${ }^{-1}$, test weight, grain yield and straw yield.

\section{Number ear heads hill ${ }^{-1}$}

The number of ear heads hill $^{-1}$ varied significantly due to the combined application of different levels of cob rind biochar and FYM (Table 3). Application of cob rind biochar@ 4 t ha ${ }^{-1}+100$ per cent Rec. FYM $\left(\mathrm{T}_{8}\right)$ recorded a higher number of ear heads hill $^{-1}$ (4.56).

However, it was found to be on par with $\mathrm{T}_{9}$ (4.32) and $\mathrm{T}_{5}$ (4.31) which received cob rind biochar@ $9 \mathrm{t} \mathrm{ha}^{-1}+75$ per cent Rec. FYM and cob rind biochar@ $2 \mathrm{t} \mathrm{ha}^{-1}+100$ per cent Rec. FYM respectively followed by application of RDF + Rec. FYM (POP) $\left(\mathrm{T}_{2}\right)$ recorded a lower value of 4.18 , but absolute control treatment $\left(\mathrm{T}_{1}\right)$ recorded the lowest value of 2.13 .

\section{Number of fingers ear head ${ }^{-1}$}

The data in Table 3 clearly showed that significantly higher number of fingers ear head $^{-1}$ was observed in $\mathrm{T}_{8}$ (7.73) which received cob rind biochar @ $4 \mathrm{tha}^{-1}+100$ per cent Rec. FYM followed by $\mathrm{T}_{9}$ (7.25) with cob rind biochar @ $4 \mathrm{t} \mathrm{ha}^{-1}+75$ per cent Rec. FYM and $\mathrm{T}_{2}$ (6.72) which received RDF + Rec. FYM (POP). The lowest number of fingers ear head ${ }^{-1}$ was recorded in absolute control $\mathrm{T}_{1}$ (3.60).

\section{Test weight}

Among the biochar levels, application of cob rind biochar@ $4 \mathrm{t} \mathrm{ha}^{-1}+100$ per cent Rec. FYM $\left(\mathrm{T}_{8}\right)$ recorded significantly higher test weight $\left(3.68 \mathrm{~g}\right.$ ) followed by $\mathrm{T}_{9}(3.59)$ which found on par with $\mathrm{T}_{5}(3.48 \mathrm{~g})$ and $\mathrm{T}_{2}(3.46 \mathrm{~g})$ which received cob rind biochar@ $4 \mathrm{t} \mathrm{ha}^{-1}+$ 75 per cent Rec. FYM, cob rind biochar@2t $\mathrm{ha}^{-1}+100$ per cent Rec. FYM and RDF + Rec. FYM (POP), respectively. Comparatively lower test weight was recorded in absolute control $\mathrm{T}_{1}(2.15 \mathrm{~g})$.

Increase in yield attributes of finger millet may be due to higher availability and constant supply of plant nutrients due to high cation exchange capacity and higher porosity of soil influenced by application of higher dose of biochar levels. Biochar has been found to increase the efficiency of fertilizer usage as stated by Dong et al., (2015); Chan et al., (2007); Chan et al., (2008) and Taghizadeh Toosi et al., (2012). The Cob rind biochar contains a high amount of total carbon, potassium, phosphorus, calcium and magnesium and it has a ability to improve the physical properties of the soil thereby increased the yield parameters like the number of ear heads hill $^{-1}$, higher number of fingers ear head ${ }^{-1}$ and test weight. Similar results were recorded by Chan et al., (2007). 


\section{Grain yield}

The data in Table 3 clearly showed that grain yield is significantly influenced by the combined application of different levels of cob rind biochar and FYM. Significantly higher grain yield of finger millet was recorded in $\mathrm{T}_{8}\left(40.88 \mathrm{q} \mathrm{ha}^{-1}\right)$ where cob rind biochar@ 4 t ha ${ }^{-1}+100$ per cent Rec. FYM was applied. But, which found on par with $\mathrm{T}_{9}$
(38.65 $\mathrm{q} \mathrm{ha}^{-1}$ ) treatment which received cob rind biochar @ 4 t ha ${ }^{-1}+75$ per cent Rec. FYM and treatment $\mathrm{T}_{5}\left(38.35 \mathrm{q} \mathrm{ha}^{-1}\right)$ which received cob rind biochar @ $2 \mathrm{t} \mathrm{ha}^{-1}+100$ per cent Rec.FYM when compared to the application of only RDF + Rec. FYM as per POP $\left(\mathrm{T}_{2}\right)$ recorded lower value of $28.59 \mathrm{q}$ $\mathrm{ha}^{-1}$. The lowest grain yield was observed in $\mathrm{T}_{1}\left(18.23 \mathrm{q} \mathrm{ha}^{-1}\right)$, with absolute control.

Table.1 Initial soil properties of the experimental site

\begin{tabular}{|c|c|}
\hline Physical properties & Value \\
\hline Sand $(\%)$ & 65.40 \\
\hline Silt $(\%)$ & 14.35 \\
\hline Clay $(\%)$ & 20.51 \\
\hline Textural class & Sandy loam \\
\hline Bulk density $\left(\mathrm{mg} \mathrm{m}^{-3}\right)$ & 1.37 \\
\hline MWHC (\%) & 33.65 \\
\hline \multicolumn{2}{|l|}{ Chemical properties } \\
\hline $\mathrm{pH}(1: 2.5)$ & 5.46 \\
\hline Electrical conductivity $\left(\mathrm{dS} \mathrm{m}^{-1}\right)(1: 2.5)$ & 0.12 \\
\hline Cation exchange capacity $\left[\mathrm{cmol}\left(\mathrm{p}^{+}\right) \mathrm{kg}^{-1}\right]$ & 8.18 \\
\hline Organic carbon $\left(\mathrm{g} \mathrm{kg}^{-1}\right)$ & 9.70 \\
\hline \multicolumn{2}{|l|}{ Available macronutrient status } \\
\hline Available $\mathbf{N}\left(\mathrm{kg} \mathrm{ha}^{-1}\right)$ & 286 \\
\hline Available $\mathrm{P}_{2} \mathrm{O}_{5}\left(\mathrm{~kg} \mathrm{ha}^{-1}\right)$ & 47.8 \\
\hline Available $\mathrm{K}_{2} \mathrm{O}\left(\mathrm{kg} \mathrm{ha}^{-1}\right)$ & 220.15 \\
\hline Exchangeable Ca $\left[\mathrm{cmol}\left(\mathrm{p}^{+}\right) \mathrm{kg}^{-1}\right]$ & 4.38 \\
\hline Exchangeable $\mathrm{Mg}\left[\mathrm{cmol}\left(\mathrm{p}^{+}\right) \mathrm{kg}^{-1}\right]$ & 2.38 \\
\hline Available $S\left(\mathrm{mg} \mathrm{kg}^{-1}\right)$ & 16.51 \\
\hline \multicolumn{2}{|l|}{ Micronutrient status (mg kg $\left.{ }^{-1}\right)$} \\
\hline Available Fe & 18.33 \\
\hline Available Zn & 1.49 \\
\hline Available $\mathbf{C u}$ & 1.05 \\
\hline Available Mn & 5.45 \\
\hline
\end{tabular}


Table.2 Effect of different levels of cob rind biochar on growth attributes at different growth stages of finger millet

\begin{tabular}{|c|c|c|c|c|c|c|c|}
\hline \multirow[t]{2}{*}{ Treatment details } & \multicolumn{3}{|c|}{ Plant height (cm) } & \multicolumn{3}{|c|}{ Number of tillers hill ${ }^{-1}$} & \multirow{2}{*}{$\begin{array}{c}\begin{array}{c}\text { Dry matter } \\
\text { accumulation } \\
\left(\mathrm{g} \mathrm{plant}^{-1}\right)\end{array} \\
\text { At harvest }\end{array}$} \\
\hline & $\begin{array}{c}\text { 30 } \\
\text { DAT }\end{array}$ & $\begin{array}{c}60 \\
\text { DAT }\end{array}$ & $\begin{array}{c}\text { At } \\
\text { harvest }\end{array}$ & $\begin{array}{c}\text { 30 } \\
\text { DAT }\end{array}$ & $\begin{array}{l}60 \\
\text { DA }\end{array}$ & $\begin{array}{c}\text { At } \\
\text { harves }\end{array}$ & \\
\hline$T_{1}$ : Absolute control & 29.40 & 56.04 & 61.52 & 0.13 & 1.28 & 1.33 & 38.12 \\
\hline$T_{2:}$ As per POP (RDF+ Rec.FYM) & 42.80 & 94.86 & 107.39 & 1.32 & 3.04 & 3.06 & 46.89 \\
\hline $\mathbf{T}_{3:}$ Cob rind biochar @ 2t ha ${ }^{-1}$ & 32.10 & 88.56 & 103.42 & 0.48 & 2.17 & 2.22 & 43.02 \\
\hline $\mathrm{T}_{4:}$ Cob rind biochar @ 4t ha ${ }^{-1}$ & 33.34 & 92.13 & 105.75 & 0.73 & 2.42 & 2.47 & 45.10 \\
\hline $\begin{array}{l}\mathrm{T}_{5}: \text { Cob rind biochar @ } 2 \mathrm{t} \mathrm{ha}^{-1}+100 \\
\% \text { Rec. FYM }\end{array}$ & 42.68 & 96.40 & 111.36 & 1.52 & 3.08 & 3.12 & 51.51 \\
\hline $\begin{array}{l}\mathrm{T}_{6} \text { : Cob rind biochar @ } 2 \mathrm{t} \mathrm{ha}^{-1}+75 \% \\
\text { Rec. FYM }\end{array}$ & 36.56 & 93.02 & 106.64 & 0.74 & 2.43 & 2.48 & 45.94 \\
\hline $\begin{array}{l}\mathrm{T}_{7} \text { : Cob rind biochar @ } 2 \mathrm{t} \mathrm{ha}^{-1}+50 \% \\
\text { Rec. FYM }\end{array}$ & 34.30 & 90.76 & 105.62 & 0.61 & 2.30 & 2.35 & 44.73 \\
\hline $\begin{array}{l}\mathrm{T}_{8} \text { : Cob rind biochar @ } 4 \mathrm{t} \mathrm{ha} \mathrm{h}^{-1}+100 \\
\% \text { Rec. FYM }\end{array}$ & 44.62 & 99.91 & 115.20 & 1.59 & 3.34 & 3.35 & 55.20 \\
\hline $\begin{array}{l}\mathrm{T}_{9}: \text { Cob rind biochar @ } 4 \mathrm{tha}^{-1}+75 \% \\
\text { Rec. FYM }\end{array}$ & 43.61 & 97.27 & 113.23 & 1.55 & 3.14 & 3.22 & $\mathbf{5 3 . 3 0}$ \\
\hline $\begin{array}{l}\mathrm{T}_{10}: \text { Cob rind biochar @ } 4 \mathrm{tha}^{-1}+50 \% \\
\text { Rec. FYM }\end{array}$ & 36.31 & 93.70 & 106.99 & 0.86 & 2.55 & 2.60 & 46.14 \\
\hline S. Em.土 & 0.60 & 1.54 & 1.89 & 0.07 & 0.07 & 0.06 & 1.51 \\
\hline C.D at $5 \%$ & 1.82 & 4.60 & 5.67 & 0.20 & 0.21 & 0.18 & 4.53 \\
\hline
\end{tabular}

Note: RDF-Recommended dose of fertilizer; Rec. FYM-Recommended dose of FYM; PoP- Package of practice

Table.3 Effect of different levels of cob rind biochar application on yield attributes and yield of fingermillet

\begin{tabular}{|c|c|c|c|c|c|}
\hline Treatments & $\begin{array}{c}\text { Number } \\
\text { of ear } \\
\text { heads hill- }\end{array}$ & $\begin{array}{c}\text { Number } \\
\text { of fingers } \\
\text { ear head }\end{array}$ & $\begin{array}{c}\text { Test } \\
\text { weight } \\
\text { (g) }\end{array}$ & $\begin{array}{c}\text { Grain } \\
\text { yield } \\
\left(\mathbf{a ~ h a}^{-1}\right)\end{array}$ & $\begin{array}{l}\text { Straw yield } \\
\left(\mathbf{q} \mathbf{h a}^{-1}\right)\end{array}$ \\
\hline$T_{1}$ : Absolute control & 2.13 & 3.60 & 2.15 & 18.23 & 31.35 \\
\hline$T_{2:}$ As per POP (RDF+ Rec. FYM) & 4.18 & 6.72 & 3.46 & 28.59 & 49.23 \\
\hline $\mathbf{T}_{3:}$ Cob rind biochar @ 2t ha ${ }^{-1}$ & 3.24 & 5.65 & 3.05 & 23.34 & 39.1 \\
\hline $\mathrm{T}_{\text {4: }}$ Cob rind biochar @ $4 \mathrm{t} \mathrm{ha}^{-1}$ & 4.03 & 6.47 & 3.30 & 25.05 & 42.01 \\
\hline $\mathrm{T}_{5}$ : Cob rind biochar @ $2 \mathrm{t} \mathrm{ha}^{-1}+\mathbf{1 0 0} \%$ Rec. FYM & 4.31 & 7.14 & 3.48 & 38.35 & 60.01 \\
\hline $\mathrm{T}_{6}:$ Cob rind biochar @ 2t ha ${ }^{-1}+75 \%$ Rec. FYM & 4.07 & 6.57 & 3.35 & 33.09 & 56.97 \\
\hline $\mathrm{T}_{7}:$ Cob rind biochar @ $2 \mathrm{t}$ ha $^{-1}+50 \%$ Rec. FYM & 3.82 & 6.32 & 3.19 & 29.78 & 53.97 \\
\hline $\mathrm{T}_{8}:$ Cob rind biochar @ $4 \mathrm{t} \mathrm{ha}^{-1}+100 \%$ Rec. FYM & 4.56 & 7.73 & 3.68 & 40.88 & 62.82 \\
\hline $\mathrm{T}_{9}$ : Cob rind biochar @ 4t ha ${ }^{-1}+75 \%$ Rec. FYM & 4.32 & 7.25 & 3.59 & 38.65 & 60.24 \\
\hline $\mathrm{T}_{10}$ : Cob rind biochar @ 4t ha ${ }^{-1}+50 \%$ Rec. FYM & 4.14 & 6.68 & 3.41 & 33.11 & 58.34 \\
\hline S. Em \pm & 0.08 & 0.12 & 0.06 & 0.93 & 1.22 \\
\hline C.D at $5 \%$ & 0.24 & 0.36 & 0.19 & 2.81 & 3.63 \\
\hline
\end{tabular}

Note: RDF-Recommended dose of fertilizer; Rec. FYM-Recommended dose of FYM; PoP- Package of practice 


\section{Straw yield}

Straw yield of finger millet differed significantly due to the application of different doses of cob rind biochar with or without FYM (Table 3). Application of cob rind biochar@ $4 \mathrm{t} \mathrm{ha}^{-1}+100$ per cent Rec. FYM $\left(\mathrm{T}_{8}\right)$ has recorded significantly highest straw yield $\left(62.82 \mathrm{q} \mathrm{ha}^{-1}\right)$, but which found on par with the $\mathrm{T}_{9}\left(60.24 \mathrm{q} \mathrm{ha}^{-1}\right)$ and $\mathrm{T}_{5}(60.01 \mathrm{q}$ $\mathrm{ha}^{-1}$ ) which received cob rind biochar @ $4 \mathrm{t}$ $\mathrm{ha}^{-1}+75$ per cent Rec. FYM and cob rind biochar@ $2 \mathrm{t} \mathrm{ha}^{-1}+100$ per cent Rec. FYM respectively, when compared to treatment $\mathrm{T}_{2}$ supplied with RDF + Rec. FYM (POP) recorded lower straw yield of $49.23 \mathrm{q} \mathrm{ha}{ }^{-1}$. But, theabsolute control treatment $\left(\mathrm{T}_{1}\right)$ recorded the lowest straw yield of 31.35 $\mathrm{q}$ ha ${ }^{-1}$.

Significant increase in grain and straw yield might be due to the biochar, which is a rich source of carbon and has capacity to increase more availability and supply of nutrients and retaining more moisture content in the soil. Increased productivity of crop with the addition of biochar might also be attributed to increased soil $\mathrm{pH}$, base saturation and $\mathrm{CEC}$ of soil, increased plant-available nutrients and water and in turn enhanced higher soil microbial activity. Higher grain and straw yield in finger millet might be due to enhanced total uptake of essential nutrients and its translocation to economic parts in addition to the improvement in yield attributing characters like the number of ear head hill ${ }^{-1}$, the number of fingers hill ${ }^{-1}$ and 1000 seeds grain weight. Similar findings in response to addition rates of biochar were reported by Chan et al., (2007); Chan et al., (2008) and Major et al., (2010).

It can be concluded from the results that, higher levels of biochar application to acid soil proved positive and beneficial effect on soil properties growth and yield of crop.
Further, addition of biochar along with FYM has improved its efficiency to a larger extent as a result significantly increased the plant growth parameters, grain and straw yield of finger millet compare to lower doses of biochar with or without FYM application.

\section{References}

Ali, K., Arif, M., Badshah, I., Zafarhayat, Ali, A., Naveed, K. and Shah, F., 2018, Formulation of biochar based fertilizer for improving maize productivity and soil fertility. Pak. J. Bot., 50(1): 135141.

Blackwell, P., Krull, E., Butler, G., Herbert, A. and Solaiman, Z., 2010, Effect of banded biochar on dryland wheat production and fertilizer use in Southwestern Australia an agronomic and economic perspective. Aust. J. Soil Res., 48: 531-545.

Chan, K. Y., Van Zwiteten, L., Meszaros, I., Downie, A. and Joseph, S., 2007, Agronomic values of green waste biochar as a soil amendment. Aust. J. Soil Res., 45: 629-634.

Chan, K. Y., Zwiteten, V. L., MESZAROS, I., Downie, A. and Joseph, S., 2008, Using poultry litter biochars as soil amendments. Aust. J. Soil Res., 46: 437444.

Dong, D., Qibo, F., Kim, M., Yang, M., Wang, H. and Wu, W., 2015, Effect of biochar amendment on rice growth and nitrogen retention in a waterlogged paddy field. J. Soils Sediments, 15: 153162.

Glaser, B., Lehmenn, J. and Zech, W., 2002, Ameliorating physical and chemical properties of highly weathered soils in the tropics with charcoal - A review. Biol. Fertil. Soils., 35: 219-230.

Gundale, M. J. and Deluca, T. H., 2006, Temperature and substrate influence the chemical properties of charcoal in the 
ponderosa pine / Douglas-fir ecosystem. Forest Ecol. Manag., 231: 86-93.

Hesu, Z. Y., Zeng, S. H., Chein, W. H. and Liuo, R. C., 2014, Impacts of biochar on physical properties and erosion potential of a mudstone slope land soil. Scientific World Journal, 10: 602-197.

Kalyani, G., Jogarao, H., Prasana, K. Y. and King, P., 2016, Potential of biochar and compost in soil amendment for enhancing crop yield.Int. J. Chem. Sci., 14(1): 173-185.

Lehmann, J., Gaunt, J. and Rondon, M., 2006, Bio-char sequestration in terrestrial ecosystems: A review. Mitig. Adapt. Strat. Gl. Chn., 11: 403-427.

Liang, B., Lehmann, J., Solomon, D., Kinyangi, J., Grossman, J., O'neill, B., Skjemstad, J. O., Thies, J., Luizao, F. J. and Petersen, J., 2006, Black carbon increases cation exchange capacity in soils. Soil Sci. Soc. Am. J., 70: 17191730.

Major, L., Rondon, M., Molina, D., Riha, S. J. and Lehmann, J., 2010, Maize yield and nutrition during four year after biochar application to a Colombian savanna Oxisol.Pl. Soil, 333: 117-128.

Schmidt, M. W. I. and Noack, A. G., 2000, Black carbon in soils and sediments: analysis, distribution, implications and current challenges. Glob.Biogeochem. Cycle., 14: 777-793.

Taghizadeh-Toosi, A., Tim, J. C., Robert, R. S. and Leo, M. C., 2012, Biochar adsorbed ammonia is bioavailable. $P l$. Soil, 350: 57-69.

\section{How to cite this article:}

Jyothishree, K. L., G. N. Thippeshappa, Sharanappa Jangandi, B. C. Dhananjaya and Kumar, O. 2020. Effect of Different Levels of Maize Cob Rind Biochar on Growth and Yield of Finger Millet. Int.J.Curr.Microbiol.App.Sci. 9(11): 168-175.

doi: https://doi.org/10.20546/ijcmas.2020.911.020 